\title{
Care for alopecia during chemotherapy of cancer patients
}

\section{암 환자의 항암화학요법 중 발생하는 탈모의 관리}

\section{Division of Breast - Thyroid Surgery, Department of Surgery, Chonbuk National University Medical School Hyun Jo Youn and Sung Hoo Jung}

\section{전북대학교 의학전문대학원 외과학교실 유방 - 갑상선외과 윤 현 조, 정 성 후}

\section{서 론}

암 환자의 항암화학요법에 따른 주요 부작용으로는 골수 억제에 의한 빈혈, 백혈구 또는 혈소판 감소증과 오심, 구토, 설사 등의 위장관 장애 그리고 탈모가 있다. 이 중 항암화학요법에 의한 탈 모(chemotherapy induced alopecia; CIA)는 약 65\% 70\%에서 발생하며, 환자들이 심리적으로 가장 큰 충격을 받는 부작용 중 의 하나로 알려져 있다.1,2) 머리카락은 열과 추위로부터 두피를 보호하는 물리적인 역할 뿐 아니라 신체 이미지를 형성하고 대인 관계를 포함한 사회 생활에도 영향을 미치기 때문에 CIA는 환자 들로 하여금 어색함, 슬픔, 혐오감, 분노 등의 우울 증상과 함께 자신감을 잃거나 성적 매력을 못 느끼고 암의 위중함에 대하여 계속 생각하게 되는 등 많은 어려움을 겪게 만든다. 이러한 증상 은 여성과 어린아이에서 특히 심한데 McGarvey 등()의 보고에 따르면 여성 암 환자의 $47 \%$ 가 탈모를 항암화학요법의 가장 심각 한 부작용으로 생각하고 있으며, 약 8\%의 환자가 탈모에 대한 두 려움으로 항암화학요법을 거부한다고 하였다. 또한 CIA의 부정 적인 심리학적 영향이 환자의 면역 기능을 억제하여 암의 진행을 유발 할 수 있다는 보고도 있다.(4)

항암화학요법에 따른 골수 억제와 위장관 장애에 대해서는 이미 많은 연구가 이루어져 이에 관한 다양한 약제들이 개발된 반면 $\mathrm{CIA}$ 는 환자 개인 뿐 아니라 사회 전반에도 영향을 미칠 수 있는 주요 부작용임에도 불구하고 이와 관련된 연구는 극히 적으며 현 재까지 효과적인 치료법 또한 알려지지 않은 실정이다. 따라서

책임저자 : 정성후

560-180, 전북 전주시 덕진구 금암동 634-18 전북대학교병원 외과 Tel: 063-250-2133 Fax: 063-271-6197 E-mail: shjung@jbnu.ac.kr 접수일 : 2011년 5월 23일 ; 게재승인일 : 2011년 6월 20일
저자들은 CIA의 특징과 병태 생리 그리고 예방 및 관리 방법에 대해 살펴보고자 한다.

\section{본 론}

\section{(1) $\mathrm{ClA}$ 의 특징}

환자들의 우려와는 다르게 항암화학요법에 사용되는 모든 항암 제가 CIA를 유발하지는 않는다. CIA의 발생과 정도는 항암제의 종류, 반감기, 용량, 투여 경로, 투여 속도 및 투여 일정에 따라 차이가 있으며 또한 환자 개개인의 특성에 따라서도 다양한 결과 를 보이는데, CIA를 잘 일으키는 항암제로는 adriamycin, epirubicin, docetaxel, paclitaxel, 그리고 cyclophosphamide 등이 있다(Table 1). Trüeb는(1) paclitaxel과 같은 항미세소관 (antimicrotubule) 제제는 $80 \%$ 이상, adriamycin과 같은 topoisomerase 억제제는 60\% 100\%, cyclophosphamide를 포 함한 알킬화(alkylating) 제제는 $60 \%$ 이상, 그리고 5Fluorouracil와 같은 대사길항제(antimetabolite)는 10\% 50\% 에서 CIA를 유발하며, 단일 약제보다 두 가지 이상의 항암제를 복합 투여할 때 더 빈번하고 심한 양상으로 발생한다고 하였다. ${ }^{(5)}$

Table 1. Cytotoxic drugs that cause chemotherapy induced alopecia and their severity.

\begin{tabular}{ccc}
\hline Mild & Moderate & Severe \\
\hline Methotrexate & 5-Fluorouracil & Adriamycin \\
Mitomycin & Busulfan & Epirubicin \\
Cisplatin & Bleomycin & Docetaxel \\
Carmustine & Gemcitabine & Paclitaxel \\
Carboplatin & Vincristine & Cyclophosphamide \\
Mercaptopurine & Mephalan & Etoposide \\
Capecitabine & Thiotepa & Ifosphamide \\
Streptozocin & Lomustine & Vindesin \\
\hline
\end{tabular}


CIA는 항암화학요법 후 1-3주 째 발생하기 시작하여 2개월 째 가장 심해지지만 대부분 일시적으로 항암제 투여가 끝나고 3-6 개월 후에는 회복된다. ${ }^{(6)}$ 그러나 고령, 고용량의 항암제, 그리고 방사선 치료가 동반된 경우에는 드물게 영구적인 탈모가 발생할 수 있으며 또한 busulfan과 cyclophosphamide 투여 후 골수 이 식을 시행 받은 경우에도 발생한 예가 보고 되었다. $(7,8)$ 따라서 항 암화학요법을 시행 받는 환자에게 치료 시작 전 CIA의 예상되는 발생 빈도와 영구적인 탈모의 가능성에 대해서 충분히 설명해주 고 동의를 얻는 것이 필요하다.

\section{(2) $\mathrm{CIA}$ 의 병태생리}

모낭(hair follicle)의 성장 주기는 생장기(anagen), 퇴화기 (catagen), 휴지기(telogen)의 세 단계로 구성된다. ${ }^{(9)}$ 모낭의 대부 분은 생장기에 속하며 활발한 세포분열을 통해 모간(hair shaft) 을 형성한다. 신체의 여러 부위 중 특히 두피는 생장기 모낭이 많 아 약 90\% 95\%를 차지하고 2 8년간 지속되어 모간이 긴 특징 이 있는 반면, 눈썹의 모낭은 수 개월의 생장기만을 거치므로 길 이가 짧은 모간을 가진다. 퇴화기는 모낭 각질세포 (keratinocyte)의 세포사멸(apoptosis)에 의한 퇴행기로 2 3주 간의 짧은 기간을 차지한다. $3 \sim 4$ 개월의 기간을 가지는 휴지기에 는 모발이 빗질 등의 외부 자극에 의해 손상될 정도로 약하다. 휴 지기에서 생장기로 이행하는 시기에 활성화된 모낭의 줄기 세포 가 기질 세포로 분화되면서 새로운 성장 주기를 시작하게 되는데 이러한 주기가 반복되면서 성인은 하루 평균 50 150개의 모발 이 빠진다. ${ }^{(10)}$

항암화학요법 시 사용하는 대부분의 항암제는 빠르게 증식하는 세포를 표적으로 하기 때문에 생장기 동안의 상피 기질 안에 있 는 각질세포는 항암제에 매우 예민하게 반응하여 모발 성장이 멈 추고 결국 탈모가 일어나게 된다. 이를 생장기 탈모증(anagen effluvium)이라고 하며 정신적 스트레스로 인한 광범위하고 일 시적인 휴지기 탈모증(telogen effluvium)과 구별된다. CIA의 가장 흔한 부위가 두피인 이유는 다른 부위의 모발에 비해 생장 기가 차지하는 비율이 높기 때문인데 여러 종류의 항암제를 고용 량으로 장기간 사용한다면 두피 뿐 아니라 눈썹, 수염, 체모 등 다른 신체 부위의 탈모도 일어날 수 있다. ${ }^{(1)}$ 그러나 모낭의 줄기 세포는 느린 성장 속도 때문에 항암화학요법의 표적에서 벗어나 시간이 경과하면 새로운 모낭과 모발이 생기게 되며, ${ }^{(2)}$ 심지어 이 러한 모발의 재성장은 항암화학요법 중에도 일어날 수 있다. ${ }^{(13)}$ 실 제 진료 현장에서 임상의들이 CIA를 겪고 있는 환자들에게 항암
화학요법만 끝나면 다시 원 상태의 모발로 돌아오니 걱정하지 말 라고 안심시키는 경우가 많은데, Batchelor에(5) 의하면 CIA 발생 후 새로 자란 모발은 약 $65 \%$ 에서 모발의 색깔이 약간 옅어지고 곱슬머리 또는 두께가 가늘어지는 구조의 변화를 보이며, 모발 성장 속도 또한 감소할 수 있다고 보고하였으므로 항암화학요법 의 설명 시 이러한 내용을 포함하는 것이 좋겠다.

$\mathrm{CIA}$ 의 분자생물학적 기전에 대해서는 아직 명확하게 밝혀지지 않았으나 Botchkarev 등(14)은cyclophosphamide로 처리한 p53 돌연변이 마우스 모델에서 Fas와 insulin-like growth factor binding protein 3 (IGFBP-3)의 저하와 $\mathrm{Bcl}-2$ 의 발현 증가에 의한 탈모 억제가 관찰되어 향후 $\mathrm{p} 53$ 억제제가 $\mathrm{CIA}$ 를 예방할 수 있는 약제로서의 가능성이 있음을 시사하였다.

\section{(3) $\mathrm{CIA}$ 의 예방}

\section{(1) 물리적 방법}

1970년대 이후 CIA를 예방하기 위한 물리적 방법에 대해 많은 연구가 이루어졌으나 현재는 두피 냉각(scalp cooling) 요법이 가 장 활발히 시행되고 있다. 두피를 차갑게 하여 혈관 수축을 유도 함으로써 모낭으로 가는 혈류를 줄여 결과적으로 항암제의 흡수 를 감소시키는 기전과 모낭의 생화학적 활성도를 감소시켜 항암 제 독성에 대한 민감도를 떨어뜨리는 기전이 원리이지만, ${ }^{(5)}$ 아쉽 게도 대부분의 보고는 그 결과가 좋지 못했다. 현재까지 총 6 편 의 무작위 대조 연구가 두피 냉각 요법의 잇점을 보고하였는데 특히 anthracyclines 또는 taxanes 계열의 항암화학요법에서 좋은 결과를 보였다. ${ }^{(16)}$ 대부분의 환자들은 두피 냉각 요법에 잘 견디지만 일부 환자에서 두통과 불편함을 호소하였으며 완치 목 적의 항암화학요법을 시행 받는 혈액학적 암 환자는 혈관 수축으 로 인하여 두피의 종양 세포에 작용하는 항암제의 효과가 감소할 수 있으므로 금기이다. ${ }^{(7)}$ 또한 두피 냉각 요법 시행 후 두피 전이 의 위험이 증가했다는 보고도 있었다. ${ }^{(18)}$

\section{(2)약물학적 방법}

여러 동물 모델에서 CIA를 예방할 수 있는 약제에 관한 연구가 시행 되었지만, 현재까지 실제 환자에서 CIA를 예방할 수 있다고 입증된 약제는 없다. CIA에 대한 약물학적 전략은 크게 두 가지 로 하나는 모발 성장을 증진시키는 것이고 다른 하나는 모발 손 실을 막는 것이다. Minoxidil은 모낭의 휴지기를 줄이고 생장기 를 늘려 모발의 성장을 자극시켜 현재 탈모 환자에게 사용되고 있는 약제인데 동물 모델에서 cytarabine에 의한 CIA를 예방할 
수 있음이 보고 되었으며, ${ }^{(19)}$ 특히 국소 minoxidil( $2 \%$ 용액)은 보 조 항암화학요법을 시행 받은 유방암 환자에서 CIA의 기간을 단 축시켰다. ${ }^{(20)}$ 그러나 동일 연구에서 CIA를 예방하지는 못했으며 busulfan과 cyclophosphamide에 의해 유도된 영구적 CIA에서 도 모발의 재성장을 유도하지 못했다. ${ }^{(8,20)}$ Cyclosporin A 또한 모 발 성장을 증진시키는 제제로 동물 모델에서 cyclophosphamide, cytarabine과 etoposide의 복합 요법에 의한 CIA를 예방하였 다. ${ }^{(21)}$ 또 다른 면역 조절자인 $\mathrm{AS} 101$ 은 carboplatin과 etoposide 에 의한 CIA를 감소시켰으나 minoxilil과 마찬가지로 실제 임상 에서 CIA를 예방하지는 못했다. ${ }^{(2)}$

항산화제(antioxidants)인 N-acetylcysteine은 항암제의 독성 을 감소시켜 모발 손실을 막는 것으로 알려져 있으며, ${ }^{(23)}$ vitamin $\mathrm{D} 3$ 는 각질세포에서 $\mathrm{DNA}$ 합성을 억제하고 $\mathrm{G} 0 / \mathrm{G} 1$ 세포 주기 정 지 및 분화 유도 등의 작용을 통해 복합항암화학요법에 의한 CIA 를 감소시켰다. ${ }^{(24)}$ Vitamin D3는 향후 CIA를 치료할 수 있는 가 장 가능성이 높은 제제로 알려져 있으나 아직까지 실제 임상에서 $\mathrm{CIA}$ 를 예방하였다는 보고는 없다. 부갑상선 호르몬과 부갑상선 호르몬 관련 펩타이드는 각질세포의 증식을 억제하고 분화를 유 도하는 것으로 알려져 있으며, 각각의 길항제는 cyclophosphamide 처치 동물 모델에서 CIA의 발생을 지연시켰 다. ${ }^{(25)}$ 세포사멸 억제제에 관한 연구도 활발히 진행되고 있는데 p53 돌연변이 동물 모델에서 cyclophosphamide 투여 후 모발 손실이 일어나지 않음을 관찰하였고, ${ }^{(4)}$ caspase-3 억제제인 M50054 (2,2-methylenebis)가 etoposide에 의한 CIA를 감소 시켰다는 보고도 있다. ${ }^{(26)}$ 또한 Davis 등 ${ }^{(27)}$ 은 cyclin-dependent kinase 2 (CDK2)의 억제가 세포 주기 정지를 유도하므로 CDK2 억제제가 향후 CIA 예방을 위한 또 다른 치료제가 될 수 있다고

Table 2. Experimental pharmacological approaches for chemotherapy induced alopecia.

\begin{tabular}{ll}
\hline \multicolumn{1}{c}{ Strategies } & \multicolumn{1}{c}{ Compound } \\
\hline Drug-specific antibody & Doxorubicin monoclonal antibody \\
Hair growth cycle modifier & Cyclosporin A, AS 101, Minoxidil \\
Cytockine & Imuvert, Interleukin-1 \\
Growth factor & EGF, FGF 1, FGF 7 \\
Antioxidant & N-acetylcysteine \\
Cell cycle or proliferation modifier & Vitamin D3, PTH and PTHrP antagonist \\
Apoptosis inhibitor & P53 inhibitor, Caspase-3 inhibitor \\
\hline
\end{tabular}

$\mathrm{EGF}=$ epidermal growth factor; $\mathrm{FGF}$ = fibroblast growth factor;

$\mathrm{PTH}=$ parathyroid hormone;

$\mathrm{PTHrP}=$ parathyroid hormone related peptide
보고하였다. CIA를 예방하기 위하여 현재까지 연구된 약제를 각 각의 기전에 따라 Table 2 에 요약 정리하였다.

CIA의 병태생리에 대해 많은 연구가 이루어지면서 이를 극복하 기 위한 다양한 약제들이 보고되고 있으나 아직 확실히 입증된 약제가 없는 이유는 대부분의 항암화학요법이 여러 항암제를 함 께 사용하는 복합 요법으로 효과적인 CIA의 예방 및 치료를 위해 서는 서로 다른 작용 기전을 가진 각각의 항암제에 모두 작용할 수 있는 제제이어야 하고, 암 세포에 대한 항암 효과는 유지하면 서 모낭 세포에만 선택적으로 작용해야 하기 때문이다. 또한 CIA 는 각 환자마다 다양한 임상 양상을 가지기 때문에 최적의 CIA 예방을 위해서는 환자 고유의 특성을 고려하여 개별적인 접근 방 법을 시도해야 한다. ${ }^{28}$

\section{(4) $\mathrm{CIA}$ 의 관리}

현재까지 CIA를 예방할 수 있는 것으로 알려진 확실한 방법이 없 으므로 항암화학요법 시행 예정인 환자에게 CIA의 특성과 함께 $\mathrm{CIA}$ 를 관리하는 방법에 관해 자세히 설명함으로써 삶의 질에 미 치는 영향을 최소화하는 것이 무엇보다 중요하다. 환자와의 충분 한 토의를 통하여 각 환자마다 다르게 느낄 수 있는 모발의 중요 성을 파악하고 탈모가 발생했을 때 나타나는 반응의 정도를 미리 예측해야 한다. 또한 환자에게 CIA에 의한 신체적 변화를 설명하 고 환자가 경험할 수 있는 정신적, 사회적 변화에 대해 충분히 상 의한 후 환자마다 정확하고 개별적인 치료를 적용한다면 심리적 안정 뿐 아니라 치료 순응도와 환자 만족도를 증가시키고 스트레 스와 우울, 불안 등의 감정을 감소시킬 수 있다.

항암화학요법 시행 후 탈모가 발생하기 전 까지는 짧고 관리하기 쉬운 헤어스타일을 유지하는 것이 좋다. 짧은 머리는 긴 머리보 다 풍성해 보이고 탈모로 인한 충격이 덜 할 수 있기 때문이다. 또한 머리카락을 보호하고 손상을 최소화하기 위해 과도한 빗질 을 피하고 이가 넓은 빗으로 부드럽게 빗질해야 한다.(5) 표백제, 과산화수소, 암모니아, 또는 알코올 등 강한 화학 성분을 함유한 제품은 사용하지 말아야 하며 순한 단백질 shampoo와 conditioner를 사용하여 일주일에 두 번 정도 머리를 감고 두피 의 각질을 제거하기 위해 부드럽게 마사지 해주는 것이 좋다. 머 리를 감은 후 말릴 때에는 공기 중에서 살살 두드리면서 말리고 헤어 드라이기는 될 수 있으면 사용하지 않는 것이 좋지만 꼭 필 요한 경우에는 가장 약한 열로 두피에서 멀리 떨어뜨려 사용한 다. 취침 시에는 공단(satin) 소재의 베개 또는 머리 망을 이용해 자는 동안 머리가 빠지는 것을 방지한다. CIA가 발생하기 전 자 
신의 취향에 맞는 가발, 모자, 스카프 등을 미리 준비해 두는 것 이 도움이 되며 이는 탈모를 감출 수 있는 효과 뿐 아니라 열이나 추위로부터 두피를 보호하는 역할도 할 수 있다. ${ }^{(29)}$

$\mathrm{CIA}$ 가 발생한 후에는 환자 스스로의 관리 전략이 필요한데 두피 의 수분을 유지하기 위해 로션이나 크림을 사용하고 두피의 가려 움을 줄이기 위해 오트밀(oatmeal)이 함유된 비누를 사용하는 것 이 좋다. 또한 외출 시에는 항암제에 예민한 눈썹을 보호하기 위 해 선글라스를 착용하는 것이 좋다. 항암화학요법을 마치고 일정 기간이 지난 후 새로 자란 머리카락은 부드러운 모발이 될 수 있 도록 적어도 모발의 길이가 $10 \mathrm{~cm}$ 가량 될 때까지 기다리고, 파마 는 항암화학요법이 끝난 후 약 9-12개월까지 연기하는 것이 좋 다. 심리적으로는 환자들이 CIA를 현실로 받아들이고 적절한 방 법을 통하여 늘 영위해오던 일상적인 삶의 형태를 지속적으로 유 지하는 것이 중요하며, CIA로 인한 불안, 우울 등의 감정 변화로 인하여 일상 생활이 어렵다고 판단되면 의료진 및 가족들에게 이 를 표현하고 도움을 받도록 권유하고 다른 환자들과의 대화를 통 하여 감정을 공유하는 것도 좋은 방법이다.

향후 환자마다 차별화된 CIA의 관리 방법을 확립하기 위해서는 환자에게 CIA에 관한 정보를 제공하는 적절한 시기, 남자, 전이 성 암 환자, 두 번째 겪는 CIA 등 특수한 상황에 대한 이해, 정서 적인 측면에서 머리를 미는(shaving)것의 영향과 같은 아직까지 해결하지 못한 논쟁에 관한 해답을 제시하는 것이 필요하다. ${ }^{(5)}$

\section{결 론}

$\mathrm{CIA}$ 는 암 환자의 치료에 있어 사회심리학적으로 많은 문제를 야 기하고 삶의 질을 저하시키는 심각한 부작용이다. CIA의 병태생 리에 대한 이해를 토대로 최근 CIA를 극복하기 위한 연구가 활발 히 진행되고 있는데 이 중 두피 냉각 요법과 minoxidil이 가장 주 목할만한 결과를 보이고 있다. 그러나, 현재까지 확실히 입증된 $\mathrm{CIA}$ 의 예방 방법은 없는 실정으로 복합항암화학요법에 사용되는 각각의 항암제에 모두 작용할 수 있는 다양한 기전을 가지고, 항 암제 효과는 저하 시키지 않으면서 모낭 세포에만 선택적으로 작 용하는 약제의 개발이 필요하다. 또한 CIA는 환자마다 다양한 임 상 양상을 보이므로 각 환자의 특성을 고려한 개별화된 접근 전 략이 필수적이다. 향후 CIA에 대한 임상적, 생물학적 그리고 심 리학적인 측면에서 효과적인 치료와 예방법에 관한 정확한 정보 를 얻기 위해서는 대규모 다기관 임상 연구가 필요할 것으로 생 각한다.

\section{REFERENCES}

1. Trüeb RM. Chemotherapy-induced hair loss. Skin Therapy Lett 2010;15:5-7.

2. Carelle N, Piotto $E$, Bellanger $A$, Germanaud J, Thuillier $A$, Khayat $D$. Changing patient perceptions of the side effects of cancer chemotherapy. Cancer 2002;95:155-163.

3. McGarvey EL, Baum LD, Pinkerton RC, Rogers LM. Psychological sequelae and alopecia among women with cancer. Cancer Pract 2001;9:283-289.

4. Spiegel D, Giese-Davis J. Depression and cancer: mechanisms and disease progression. Biol Psychiatry 2003;54:269-282.

5. Batchelor D. Hair and cancer chemotherapy: consequences and nursing care-a literature study. Eur J Cancer Care 2001;10:147-163.

6. Dorr VJ. A practitioner's guide to cancer-related alopecia. Semin Oncol 1998;25:562-570.

7. Tallon B, Blanchard E, Goldberg LJ. Permanent chemotherapyinduced alopecia: case report and review of the literature. J Am Acad Dermatol 2010;63:333-336.

8. Tran D, Sinclair RD, Schwarer AP, Chow CW. Permanent alopecia following chemotherapy and bone marrow transplantation. Australas J Dermatol 2000;41:106-108.

9. Paus R, Cotsarelis $\mathrm{G}$. The biology of hair follicles. N Engl J Med 1999;341:491-497.

10. Hesketh PJ, Batchelor D, Golant M, Lyman GH, Rhodes N, Yardley D. Chemotherapy-induced alopecia: psychosocial impact and therapeutic approaches. Support Care Cancer 2004;12:543-549.

11. Wang J, Lu Z, Au JL. Protection against chemotherapyinduced alopecia. Pharm Res 2006;23:2505-2514.

12.. Cotsarelis G, Millar SE. Towards a molecular understanding of hair loss and its treatment. Trends Mol Med 2001;7:293-301.

13. Pickard-Holley S. The symptom experience of alopecia. Semin Oncol Nurs 1995;11:235-238.

14. Botchkarev VA, Komarova EA, Siebenhaar F, Botchkareva NV, Komarov PG, Maurer M, et al. p53 is essential for chemotherapyinduced hair loss. Cancer Res 2000;60:5002-5006.

15. Bülow J, Friberg L, Gaardsting $O$, Hansen M. Frontal subcutaneous blood flow, and epi- and subcutaneous temperatures during scalp cooling in normal man. Scand J Clin Lab Invest 1985;45:505-508.

16. Macduff $C$, Mackenzie T, Hutcheon A, Melville $L$, Archibald $H$. The effectiveness of scalp cooling in preventing alopecia for patients receiving epirubicin and docetaxel. Eur $\mathrm{J}$ Cancer Care 2003;12:154-161.

17. Grevelman EG, Breed WP. Prevention of chemotherapyinduced hair loss by scalp cooling. Ann Oncol 2005;16:352-358.

18. Forsberg SA. Scalp cooling therapy and cytotoxic treatment. Lancet 2001;357:1134. 
19. Hussein AM. Protection against cytosine arabinoside-induced alopecia by minoxidil in a rat animal model. Int $\mathrm{J}$ Dermatol 1995;34:470-473.

20. Duvic M, Lemak NA, Valero V, Hymes SR, Farmer KL, Hortobagyi $\mathrm{GN}$, et al. A randomized trial of minoxidil in chemotherapy-induced alopecia. J Am Acad Dermatol 1996;35:74-78.

21. Hussein AM, Stuart $A$, Peters WP. Protection against chemotherapy-induced alopecia by cyclosporin $A$ in the newborn rat animal model. Dermatology 1995;190:192-196.

22. Sredni $B$, Xu RH, Albeck M, Gafter U, Gal R, Shani A, et al. The protective role of the immunomodulator AS101 against chemotherapy-induced alopecia studies on human and animal models. Int J Cancer 1996;65:97-103.

23. D'Agostini F, Bagnasco M, Giunciuglio D, Albini A, De Flora S. Inhibition by oral $\mathrm{N}$-acetylcysteine of doxorubicin-induced clastogenicity and alopecia, and prevention of primary tumors and lung micrometastases in mice. Int J Oncol 1998;13:217-224.

24. Jimenez JJ, Yunis AA. Vitamin D3 and chemotherapy-induced alopecia. Nutrition 1996;12:448-449.

25. Peters EM, Foitzik K, Paus R, Ray S, Holick MF. A new strategy for modulating chemotherapy-induced alopecia, using PTH/PTHrP receptor agonist and antagonist. J Invest Dermatol 2001;117:173-178.

26. Tsuda T, Ohmori $Y$, Muramatsu H, Hosaka $Y$, Takiguchi $K$, Saitoh F, et al. Inhibitory effect of M50054, a novel inhibitor of apoptosis, on anti-Fas-antibody-induced hepatitis and chemotherapy-induced alopecia. Eur J Pharmacol 2001;433:37-45. 27. Davis ST, Benson BG, Bramson HN, Chapman DE, Dickerson $\mathrm{SH}$, Dold KM, et al. Prevention of chemotherapy-induced alopecia in rats by CDK inhibitors. Science 2001;291:134-137.

28. Yun SJ, Kim SJ. Hair loss pattern due to chemotherapyinduced anagen effluvium: a cross-sectional observation. Dermatology 2007;215:36-40.

29. Rosman S. Cancer and stigma: experience of patients with chemotherapy-induced alopecia. Patient Educ Couns 2004;52:333-339. 


\title{
Care for alopecia during chemotherapy of cancer patients
}

\author{
Division of Breast - Thyroid Surgery, Department of Surgery, Chonbuk National University Medical School \\ Hyun Jo Youn and Sung Hoo Jung
}

\section{Abstract}

Chemotherapy induced alopecia (CIA) is one of the most common and emotionally traumatic side effects in cancer patient care. CIA occurs with an estimated incidence of $65 \%$ and negatively affects a patient ${ }^{\circ} \emptyset$ s perception of appearance, body image, attractiveness, and self-esteem. Patient who fear CIA may select regimens with less favorable outcomes or may refuse treatment.

$\mathrm{CIA}$ is caused by certain chemotherapeutics such as anthracyclines and taxanes. The incidence and severity of CIA depends on dose, administration route, rate, schedule, and peak blood level of the drug. The keratinocytes of hair follicle are susceptible to apoptosis induced by chemotherapeutics. Fortunately, CIA is usually reversible but permanent $\mathrm{CIA}$ also has been reported.

The major approaches to prevent or minimize CIA are by physical and pharmacological means. Several experimental studies to the development of pharmacological agents to overcome CIA are under evaluation. However, effective methods for preventing CIA are currently unavailable.

The management of $\mathrm{CIA}$ must be individualized based on the needs of each patient. An effective CIA treatment would likely require agents that are effective for chemotherapeutics with different action mechanisms and selective to hair follicles.

Key Words : Chemotherapy induced alopecia, hair follicle, pharmacological agents, individualization

Correspondence :Sung Hoo Jung M.D., Ph.D.

Division of Breast - Thyroid Surgery, Department of Surgery, Chonbuk National University Medical School, Jeonju 560-180, Korea Tel: 82-63-250-2133 Fax: 82-63-271-6197 E-mail: shjung@jbnu.ac.kr

Received : May 23, 2011 ; Accepted : Jun 20, 2011 